\title{
An Explanation of the Black Color of River Nyong Water's and Associated Alluviums (Cameroon)
}

\author{
Samba Assomo Philippe1* ${ }^{*}$, Chi Cheyneysu Emmanuel Toussaints ${ }^{2}$, \\ Kamgang Kabeyene Beyala Veronique ${ }^{3}$ \\ ${ }^{1}$ Faculté des Sciences, Université de Yaoundé I, Yaoundé, Cameroun \\ ${ }^{2}$ Organisme Environnemental MIEUX-ETRE, Douala, Cameroun \\ ${ }^{3}$ Ecole Normale Supérieur, Université de Yaoundé I, Yaoundé, Cameroun \\ Email: *sambafilipe@yahoo.fr
}

Received 21 January 2015; accepted 5 April 2015; published 10 April 2015

Copyright (C) 2015 by authors and Scientific Research Publishing Inc.

This work is licensed under the Creative Commons Attribution International License (CC BY). http://creativecommons.org/licenses/by/4.0/

(c) (i) Open Access

\begin{abstract}
The River Nyong is situated in Akonolinga (central-south of Cameroon). In order to search for raw materials in ceramic use, samples of alluvium obtained from the deposits in the Nyong River clays have been studied. The results obtained show that, the samples contain important quantity of organic matter and the soil is acidic.These two parameters are necessary to understand the origin of the characteristic color of alluvium and water of the River Nyong.
\end{abstract}

Keywords

Nyong River, Black Color, Akonolinga, Alluvium, Water

\section{Introduction}

The characteristic color of alluvium and water of the River Nyong appears as an exceptional phenomenon in Southern Cameroon. Usually, the water color of rivers changes with seasons and raining events. This is linked to the geological environment. The curiosity is that, among many rivers sharing the same area, the River Nyong is the only one which contains dark alluvium and water. This is the reason why the origin of that characteristic color should be understood in order to extend this comprehension in others cases. The significance of this study is to determine the origin of the dark color of alluvium and the dark water in River Nyong in Akonolinga.

${ }^{*}$ Corresponding author.

How to cite this paper: Philippe, S.A., Toussaints, C.C.E. and Veronique, K.K.B. (2015) An Explanation of the Black Color of River Nyong Water's and Associated Alluviums (Cameroon). International Journal of Geosciences, 6, 388-392. 


\section{Situation of the Field Studied}

The field studied extended from latitude $3^{\circ} 27^{\prime}$ to $4^{\circ} 47^{\prime} \mathrm{N}$ and from latitude $11^{\circ} 36^{\prime}$ to $12^{\circ} 43^{\prime} \mathrm{E}$ (Figure 1 ). The coordinates of pedological excavations, in which samples of clay have been taken, are as followed: P1: N03 46'08" and E012 ${ }^{\circ} 14^{\prime} 41^{\prime \prime}$; P2: N03 46'07" and E012 ${ }^{\circ} 14^{\prime} 32^{\prime \prime}$; P3: N03 ${ }^{\circ} 46^{\prime} 02^{\prime \prime}$ and E012 ${ }^{\circ} 14^{\prime} 3$. The river covers an area of $27800 \mathrm{~km}^{2}$ and his bed is deep at $650 \mathrm{~m}$ of altitude in marshy valley, in the equatorial forest: Ndam, 1997 [1]; Bineli, 2009 [2] and Samba, 2008 [3]. This field is submitted to the equatorial climate with four seasons.
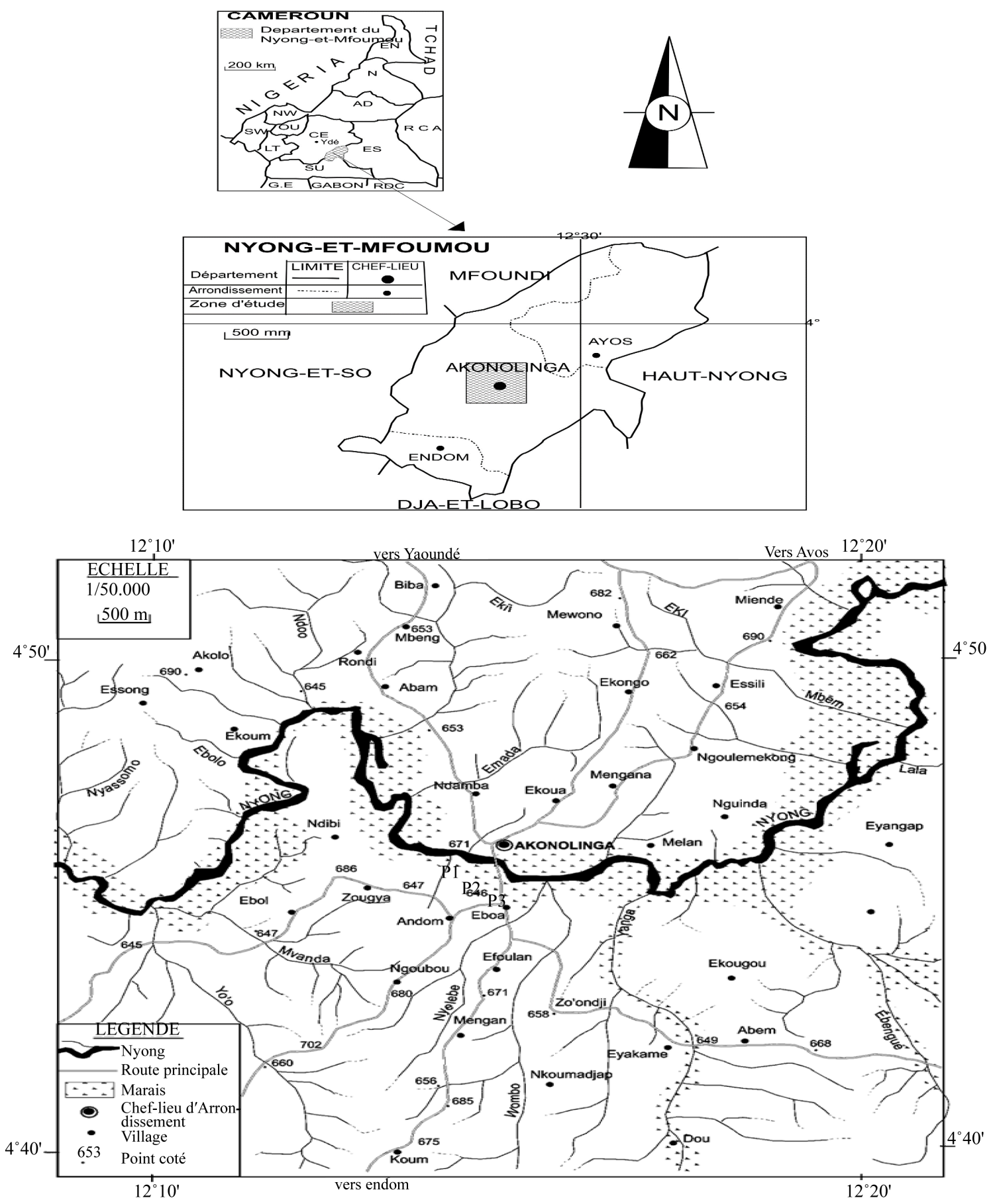

Figure 1. Location of studied field. 


\section{Materials and Methodology}

To open pedological excavations (P1, P2 and P3), in which samples were collected, manual work materials were usually used. A digital camera, a laptop and the GPS were used. The sample were packaged in plastic bags and sent to the laboratory (IRAD-Yaoundé) to determine the quantity of organic matter, the granular composition, and the acidity of the soil. Four levels of test samples were defined notably at $0 \mathrm{~cm}, 20 \mathrm{~cm}, 50 \mathrm{~cm}$ and $80 \mathrm{~cm}$.

The determination of the various parameters was made after drying, grinding and sieving of samples. The organic carbon is determined according to the method of oxidation to the dichromate of potassium of Walkley and Black. The comparable phosphor is measured according to the method of Bray2. It is extracted by a mixture of $\mathrm{HCl}$ and $\mathrm{NaF}$ while the soluble phosphor is extracted according to the method Olsen in the $\mathrm{NaHCO}_{3} 0.5 \mathrm{~mol} / \mathrm{l}$ in $\mathrm{pH} 8.50 \pm 0.02$. The $\mathrm{pH}_{\text {water }}$ is measured in a solution ground/water solution ratio of $1 / 2.5$, with a $\mathrm{pH}$-meter provided with a glass electrode and the $\mathrm{pH}_{\mathrm{KCl}}$ is obtained by realizing in the same proportions a mixture normal ground/KCl. The total nitrogen is determined according to the method Kjedhal. The cation exchange capacity is estimated by colorimetry at 655 nanometer of wavelength spectrometry. The granulometry was performed according to the method of Robinson pipette.

\section{Presentation and Interpretation of Results}

The results were separated in three groups: the organic matter; the granulometry and the acidity of the soil.

\subsection{Organic Material}

The important quantity of organic matter is accumulated on the surface (Table 1). Other chemical elements such as carbon or nitrogen have the same evolution. The ratio $\mathrm{C} / \mathrm{N}$ indicates the poor mineralization process; Meyim, 2000 [4]. This is linked to the lack of oxygen in the soil. The consequence is the limitation of microbial activities: Evans and Kamparath, 1970 [5]; Enyegue, 2012 [6]; Voundi Nkana, 2000 [7].

\subsection{Granulometry}

Three granular families were obtained (clay, silt and sand). From Table 2, different percentages were calculated. The percentage of clay 55.3\% is the most important followed by silt $30.56 \%$ and the sand closes the list with $14.14 \%$. The prevalence of clay associated to silt gives to the soil the clayey texture, which can explain the permanent overflowing of the valley during the raining season. The porosity and the permeability are reduced because of the poor distribution of the sand.

\subsection{Acidity}

The soil is acidic (Table 3). Different values of PH are almost inferior to 5. The values of pKCl 1:1.25 are

Table 1. Distribution of organic matter.

\begin{tabular}{ccccccccccccc}
\hline $\begin{array}{c}\text { Code of } \\
\text { samples }\end{array}$ & A1NY & A1NY & A1NY & A1NY & A2NY & A2NY & A2NY & A2NY & A3NY & A3N & A3NY & A3NY \\
\hline Org Mat. $\%$ & 16.91 & 14.95 & 13.48 & 7.24 & 14.02 & 6.69 & 1.99 & 2.08 & 15.62 & 3.47 & 2.34 & 2.02 \\
C \% & 9.83 & 8.69 & 7.84 & 4.21 & 8.15 & 3.89 & 1.16 & 1.21 & 9.08 & 2.02 & 1.36 & 1.16 \\
N \% & 1.80 & 1.28 & 3.75 & 0.09 & 3.56 & 0.23 & 0.07 & 0.08 & 0.80 & 0.22 & 0.06 & 0.08 \\
C/N & 5.46 & 6.79 & 2.12 & 46.78 & 2.29 & 16.91 & 16.57 & 15.13 & 11.35 & 9.18 & 22.67 & 14.05 \\
\hline
\end{tabular}

Table 2. Granulometry.

\begin{tabular}{cccccccccccccc}
\hline Clay \% & 23.50 & 50.25 & 25.50 & 21.50 & 38.00 & 65.50 & 70.25 & 53.25 & 51.00 & 62.50 & 62.75 & 56.75 \\
\hline Fine limon \% & 21.50 & 18.15 & 17.75 & 4.75 & 21.25 & 16.25 & 8.25 & 9.00 & 18.50 & 17.00 & 13.50 & 10.75 \\
Large limon \% & 5.20 & 11.20 & 11.61 & 18.86 & 6.82 & 9.75 & 9.11 & 24.15 & 8.66 & 11.13 & 12.86 & 14.86 \\
Fine sand \% & 5.43 & 12.35 & 30.50 & 48.37 & 3.52 & 1.17 & 1.09 & 10.34 & 5.55 & 5.15 & 6.45 & 13.24 \\
Large sand \% & 0.06 & 0.18 & 2.20 & 1.74 & 0.07 & 0.11 & 0.04 & 0.08 & 0.18 & 0.20 & 0.27 & 0.27 \\
\hline
\end{tabular}


Table 3. Acidity/alkalinity.

\begin{tabular}{cccccccccccccc}
\hline pHwater 1:2.5 & 5.03 & 5.15 & 4.55 & 4.72 & 4.74 & 4.77 & 4.87 & 4.86 & 4.58 & 4.90 & 5.03 & 5.12 \\
pKCl 1:2.5 & 3.85 & 4.78 & 3.82 & 3.89 & 3.90 & 3.82 & 3.72 & 3.74 & 3.85 & 3.93 & 4.02 & 4.03 \\
\hline
\end{tabular}

situated between 4.75 and 5.12, those of PH water evolved from 3.72 to 4.03 . This situation limits the activity of decomposers microorganisms and creates the accumulation of organic matter.

\section{Discussion}

The works of several authors have studied the origin of the color of the water. According to Davis and Milligan, 2011 [8], the blue color of lakes and oceans is closely related to that of heaven. This is due to reflections mechanisms and absorption of light radiation. It is a differential absorption of some radiation in the electromagnetic spectrum of white light: Pope and Jery, 1996 [9]; Hoge, Vodacek, Swift, Yungel and Blough, 1995 [10]. For cons, the difference established by Jansen 1974 [11]; between the white and black water rivers and streams only considers their mineral composition. Thus, the black waters are rich in aluminum, while the clear waters are rich in calcium ions, potassium. According to the same author, the abundance of ferric ions can make ocher the color of water. However, in forests, several authors show that the presence of organic matter in solution is responsible for the black color of river waters: [11]; Sioli and Harald, 1975 [12]; Duncan and Fernandes, 2010 [13]. These last results are in agreement with those obtained in the Nyong because the alluvial samples in the floodplain of the river revealed the presence of large amounts of organic matter. The peculiarity in the Nyong is that, the black color of the river water also affects the alluvium of the valley. Two major facts may justify this combination: the accumulation of decaying organic matter in the valley and the regular flooding of the latter by the black waters of Nyong River which may contaminate the alluvium.

\section{Conclusion}

Due to the accumulation of important quantities of organic matter in the valley of River Nyong in Akonolinga, it has made the water and the alluvium to be black. This black color of the alluvium and water is also facilitated by the acidity of the valley, the absence of oxygen, the poor activities of microorganisms and the presence of impermeability clay layer. The dissolving of the organic matter in these conditions justifies the black color of the water and associated alluvium.

\section{References}

[1] Ndam, J. (1997) Bilans hydrogéochimiques sous forêt tropical aux réseaux hydrographiques du Nyong et de la Sanaga au Sud Cameroun. Th. Doc., Univ. Pierre et marie Curie, Paris, 214 p.

[2] Bineli, E. (2009) Impact de la variabilité climatique sur les ressources en eau du bassin du Nyong. Mém. DEA. FAC. Sc. UYI., 82 p.

[3] Samba, A. (2008) Caractérisation géotechnique des argiles alluvionnaires de la vallée du Nyong dans la région d'Akonolinga. Press CAMES, Série A, 11 p.

[4] Meyim, D. (2000) Effet des diverses jachères sur l'évolution de la fertilité d’un sol ferralitique des environs de Yaoundé (Cameroun). Mém. DEA. Fac. Sc Univ Ydé I, 60 p.

[5] Evans, C. and Kamparath, E. (1970) Lime Response and Related to Percent Aluminium Saturation, Solution Al and Organic Matter Content. Soil Science Society of America, Proceedings, 34, 893-896. http://dx.doi.org/10.2136/sssaj1970.03615995003400060023x

[6] Enyegue, A. (2012) Fertilité et aptitudes culturales des sols de SA’A développés sur micaschistes grénatifères. Mem. DIPES II. ENS: UYI., 75 p.

[7] Voundi Nkana, J. (1998) Utilisation des déchets de l'industrie du bois en vue de l'amélioration de la fertilité chimique des sols acides tropicaux. Th. Doct., $3^{\text {ème }}$ cycle, IRAD, 202 p.

[8] Davis, J. and Milligan, M. (2011) Why Is Bear Lake So Blue? Public Information Series 96, Utah Geological Survey, 10.

[9] Pope, R.M. and Fry, E.S. (1996) Absorption Spectrum (380 - 700 nm) of Pure Water. II. Integrating Cavity Measurements. Applied Optics, 36, 8710-8723. http://dx.doi.org/10.1364/AO.36.008710 
[10] Hoge, F., Vodacek, A., Swift, R., Yungel, J. and Blough, N. (1995) Inherent Optical Properties of the Ocean: Retrieval of the Absorption Coefficient of Chromophoric Dissolved Organic Matter from Airborne Laser Spectral Fluorescence Measurements. Applied Optics, 34, 7032-7038. http://dx.doi.org/10.1364/AO.34.007032

[11] Janzen, D. (1974) Tropical Blackwater Rivers, Animals, and Mast Fruiting by the Dipterocarpaceae. Biotropica, 6, 69-103. http://dx.doi.org/10.2307/2989823

[12] Sioli, H. (1975) Tropical Rivers as Expressions of Their Terrestrial Environments. In: Tropical Ecological Systems/ Trends in Terrestrial and Aquatic Research, Springer-Verlag, New York City, 275-288. http://dx.doi.org/10.1007/978-3-642-88533-4_19

[13] Duncan, W. and Fernandes, M. (2010) Physicochemical Characterization of the White, Black, and Clearwater Rivers of the Amazon Basin and Its Implications on the Distribution of Freshwater Stingrays (Chondrichthyes, Potamotrygonidae). PanamJAS, 5, 454-464. 